\title{
RESPON MAHASISWA TERHADAP PEMBELAJARAN MENGGUNAKAN GOOGLE CLASSROOM DI MASA PENDEMI COVID-19 PADA MATA KULIAH KONSEP DASAR PKN
}

\author{
Edy Suparjan ${ }^{1}$, Arif Hidayad ${ }^{2}$ Ilyas $^{3}$, Zulkifli ${ }^{4}$, M. Nurimansyah ${ }^{5}$ \\ 1,2,3,4 STKIP Taman Siswa Bima, ${ }^{5}$ STKIP Yapis Dompu \\ Itanmaedysu@gmail.com²arif.hidayad88@gmail.com³ilyas.stkiptsb@gmail.com, \\ ${ }^{4}$ ijulk.bima@gmail.com, 5 mnurimansyah000@gmail.com
}

\begin{abstract}
Abstrak : Pendemi Virus Corona memaksa sistem pendidikan di Indonesia untuk menggunakan pembelajaran dalam jaringan mulai tingkat SD sampai Perguruan Tinggi, hal ini membuat guru dan dosen untuk menyesuaikan kebiasaan baru tersebut dengan melakukan pembelajaran online menggunakan aplikasi dalam jaringan internet. Adapun tujuan penelitian ini untuk mengetahui seberapa besar respon dan kesiapan mahasiswa dalam menggunakan aplikasi google classroom sehingga dapat mempermudah dosen dan mahasiswa dalam berinteraksi dalam pembelajaran. Penelitian ini menggunakan jenis penelitian kualitatif deskriptif dengan tehnik survey dalam mengumpulkan data dilapangan. Sampel terdiri dari 70 orang mahasiswa semester 1 PGSD dibagi dalam 2 kelas yaitu kelas $G$ sejumlah 30 orang dan Kelas H 40 orang. Angket diberikan kepada mahasiswa yang sedang mengikuti pembelajaran daring Mata Kuliah Konsep Dasar PKN. Jumlah pertanyaan diberikan sebanyak 15 pertanyaan dengan pilihan jawaban Sangat tidak setuju, Setuju, Ragu, Tidak Setuju, Sangat tidak setuju. Hasil penelitian ditemukan bahwa rata-rata respon mahasiswa terhadap penggunaan Google Classroom pada tiap indikator penelitian adalah paling tinggi pada indikator pertama sebanyak 78,29\% di Kelas G dan indikator pemahaman materi dalam google classroom sebesar 71,12\% berada pada kategori setuju. Sementara di Indikator pertama tentang kemudahan mahasiswa menggunakan google classroom pada Kelas H sebesar 75,33\% dan Indikator Pemahaman Materi dalam Google Classroom sebesar 75,16\% yaitu berada pada kategori setuju.
\end{abstract}

Kata Kunci; Respon, pembelajaran, Google Classroom, Masa Covid

\begin{abstract}
The Corona Virus pandemic forces the education system in Indonesia to use online learning from elementary to tertiary level, this makes teachers and lecturers to adapt to this new habit by doing online learning using applications on the internet network. The purpose of this study is to find out how much the response and readiness of students in using the google classroom application so that it can make it easier for lecturers and students to interact in learning. This research uses descriptive qualitative research with survey techniques in collecting data in the field. The sample consisted of 70 PGSD 1st semester students divided into 2 classes, 30 students in $G$ class and 40 students in $H$ class. The questionnaire was given to students who were taking online learning in the Basic Concepts of PKN. The number of questions given is 15 questions with answer choices; Strongly disagree, Agree, Doubt, Disagree, Strongly disagree. The results of the study found that the average student response to the use of Google Classroom on each research indicator was the highest in the first indicator as much as $78.29 \%$ in Class $G$ and the indicator of material understanding in google classroom by $71.12 \%$ in the agree category. While the first indicator about the ease with which students use google classroom in Class $H$ is $75.33 \%$ and the Material Understanding Indicator in Google Classroom is 75.16\%, which is in the agree category.
\end{abstract}

Keywords; Response, Learning, Google Classroom, Covid 19

\section{PENDAHULUAN}

Pendemi Virus Corona memberi efek pada aspek pendidikan sehingga harus menggunakan metode pembelajaran online berbasis internet. Bagaimana juga masalah Covid 19 merupakan musibah dunia yang melibatkan lembaga dunia seperti WHO. Menurut data WHO bahwa pada tanggal 11 September 2020 pemerintah Indonesia telah mengumumkan bahwa ada sekitar 210.940 kasus yang telah terkonfirmasi. Sementara ada 3.737 kasus baru. Kemudian ada 8.544 kasus kematian karena virus dan kasus baru 88 orang dan 150.217 telah dinyatakan sembuh dari covid 19. Data ini berdasarkan akumulasi dari 490 Kabupaten dan Kota di 34 Propinsi seluruh Indonesia. www.who.int. (diakses pada tanggal 06 Februari 2021).

Sementara masalah Covid 19 belum mampu dihilang dari kehidupan sosial masyarakat dunia karena tiap bulannya terus meningkat walaupun tidak terlalu banyak. Berdasarkan data Gugus Covid 19 untuk wilayah propinsi Nusa Tenggara Barat angka kasus covid 19 tertinggi di Kota Mataram 
disusul oleh Lombok Barat dan Lombok Timur, berturut-turut sebanyak 722 Kasus, 145 Kasus dan 100 kasus di Lombok Timur. Sementara berada pada posisi terendah adalah Kota Bima hanya 1 kasus kemudian sumbawa barat sebanyak 12 kasus dan kabupaten Bima sendiri terdapat 25 kasus. www.covid19.go.id (diakses tanggal 06 Februari 2021).

Virus corona telah memberikan dampak yang sangat berpengaruh diberbagai aspek kehidupan baik sosiologis, politik, ekonomi dan juga pendidikan. Secara regulasi pemerintah terdesak untuk segera mengeluarkan aturan baru terkait pelaksanaan sistem pendidikan termasuk kurikulum sehari dan kegiatan pembelajaran dilakukan dirumah bagi siswa dan guru. Diberbagai level pendidikan mulai SD sampai tingkat perguruan tinggi ramai-ramai menggunakan sistem pembelajaran online atau dalam jaringan. Pihak Kementerian Pendidikan Tinggi mengeluarkan kebijakan untuk menyiapkan quota paket bagi guru, dosen serta mahasiswa. Hal ini dilakukan agar memberikan kemudahan bagi para guru dan dosen serta mahasiswa dalam melakukan akses internet baik di kampus maupun dirumah.

Namun, disisi lain dalam penggunaan teknologi juga tetap ada masalah diantaranya menurut, Syah Aji, (2020) adanya keterbatasan penguasaan teknologi informasi oleh guru dan siswa, masih kurangnya sarana dan prasarana, guru dan siswa memiliki akses internet yang terbatas serta kurangnya siap penyediaan anggaran. Berdasarkan pendapat Syah Aji tersebut dapat dibenarkan karena masih banyak daerah-daerah pelosok indonesia yang belum mampu dijangkau oleh jaringan internet. Walaupun pihak kementerian telah menyediakan paket internet untuk guru dan siswa.

Pembelajaran dalam jaringan memiliki banyak alternatif diantaranya Guru dan Dosen dapat melakukan pertemuan tatap muka dengan mahasiswa dengan menggunakan aplikasi zoom meeting, ada juga Dosen yang menjelaskan materinya lewat blogger maupun website pribadi, serta mengirim tugas-tugas mahasiswa lewat email maupun via whatsup. Selain itu, Dosen menggunakan aplikasi google classroom sebagai media pembelajaran. Dimana google classroom memiliki banyak sekali tampilan yang dapat digunakan oleh dosen baik dalam mengupload materi-materi, video-video pembelajaran serta dosen dapat juga memberikan kuis atau soal-soal tanya jawab yang dapat dijawab langsung oleh mahasiswa kemudian memberikan penilaian langsung pada aplikasi tersebut. Bahkan mahasiswa tidak repot melihat nilainya. Dengan kemudahankemudahan seperti itu mahasiswa dapat belajar serta mengumpulkan tugas dimanapun berada tidak dibatasi oleh ruang dan waktu.

Menurut (Deni, 2012) sistem $e$ learning merupakan suatu bentuk implementasi teknologi yang ditujukan untuk membantu proses pembelajaran yang dikemas dalam bentuk elektronik/digital dan pelaksanaannya membutuhkan sarana komputer berbasis web dalam situs internet. Tujuannya adalah meningkatkan kualitas pembelajaran dengan berupaya menembus keterbatasan ruang dan waktu. Namun, seiring dengan berjalan waktu teknologi semakin canggih mahasiswa dapat menggunakan handphone mendownload aplikasi google classroom, dosen mengirim kode kelas. Mahasiswa langsung dapat berinteraksi dengan dosennya.

Menurut (Azhar, 2014) salah satu kelebihan internet adalah telah menyediakan media pembelajaran. Orang-orang, siswa dan dosen tidak perlu repot keperpustakaan cukup masuk layanan www.google.com dan melakukan pencarian, maka disana telah tersedia. Bahkan dengan kecanggihan teknologi google telah menyediakan segala macam fitur diantaranya; blogspot, google doc, google slide, google meet sampai google classroom sebagai ruang kelas.

Lebih lanjut, Menurut Azhar, (2014:204) implementasi internet pada aspek pendidikan dikenal e-learning atau pembelajaran jarak jauh. Hal ini mempermudah mahasiswa dalam kegiatan perkuliahan, seperti mahasiswa yang ingin melihat nilai secara online, jadwal kuliah dan mengirimkan berkas tugas.

Aplikasi google classroom memiliki kelebihan diantaranya mahasiswa mudah melakukan instal gratis, mahasiswa dapat melakukan upload dan pengunduhan dokumen secara gratis serta file-file yang di upload secara otomatis tersimpan di google drive yang suatu waktu dapat digunakan kembali oleh mahasiswa maupun dosen.

Menurut

(Pribadi, mengemukakan bahwa definisi belajar adalah rangkaian kegiatan yang sengaja dirancang secara sistematis dalam mencapai tujuan pembelajaran tertentu sehingga dapat meningkatkan kemampuan peserta didik. Hal 
itulah mengapa google classroom sebagai media yang dirancang khusus sebagai upaya untuk mencapai tujuan pembelajaran yang dicapai. Sejalan dengan itu, Menurut Ragan dalam Pribadi (2015:15) untuk mencapai keberhasilan pembelajaran harus memenuhi tiga faktor yaitu, efektifitas, efisiensi dan daya tarik. Aplikasi google Classroom merupakan media pembelajaran yang sangat efektif digunakan oleh mahasiswa serta memiliki daya tarik tersendiri, karena aplikasinya sangat membantu mahasiswa dalam memberikan kemudahan-kemudahan mahasiswa dalam hal pembelajaran.

Penelitian terdahulu dilakukan oleh (Maskar \& Wulantina, 2019) dengan judul "Persepsi Peserta Didik terhadap Metode Blended Learning dengan Google Classroom" yang menunjukkan hasil penggunaan Google Classroom dapat meningkatkan minat belajar peserta serta meningkatkan proses belajar mandiri. Selain itu, metode ini juga dapat meningkatkan pemahaman dan hasil belajar peserta didik. Yaitu pemahaman materi menggunakan google Classroom memperoleh nilai tertinggi yaitu sebesar $62,63 \%$.

Sementara hasil penelitian (Suhada \& et.al, 2020) menunjukan bahwa pembelajaran daring berbasis google classroom pada mahasiswa pendidikan biologi pada masa wabah covid-19 dapat disimpulkan bahwa penggunaan aplikasi google classroom akan sangat efektif apabila dipadukan dengan platform aplikasi online lainnya. Peneliti lain, seperti Rosali, (2020) menyatakan bahwa pembelajaran daring di masa pendemi covid 19 cukup efektif bila menggunakan aplikasi google classroom dan whatshapp. Kemudian Pratiwi, (2020) dalam penelitiannya menemukan masalah utama dalam pembelajaran daring adalah masalah quota dan keterbatasan jaringan internet.

Berdasarkan penelitian (Arifin \& Merdekawati, 2020) bahwa rata-rata mahasiswa setuju bahwa pemanfaatan Google Classroom dalam proses belajar mengajar pada mata kuliah Metode Penelitian Penulisan Laporan dapat meningkatkan produktivitas dalam pembelajaran. Mahasiswa juga senang menggunakan Classroom dalam pembelajaran dan mahasiswa menganggap bahwa pemanfaatan Google classroom dapat menghemat biaya dan dapat mengakses kapan saja. Kemudian, hasil penelitian (Utami, 2019) menunjukan bahwa pembelajaran Google
Classroom mendapatkan respon yang baik dari mahasiswa, sehingga dapat digunakan untuk pembelajaran pada matakuliah Psikologi Pembelajaran Matematika ataupun pada matakuliah yang lain.

Program Studi Pendidikan Guru Sekolah Dasar STKIP Taman Siswa Bima adalah salah satu program studi di Perguruan Tinggi STKIP Taman Siswa Bima yang telah menggunakan aplikasi google Classroom sejak diberlakukannya pembelajaran dalam jaringan oleh Kemendikbud yaitu pada tahun 2019/2020 dan sampai sekarang aplikasi google Classroom tetap digunakan demi membatasi pertemuan dalam skala besar, hal ini tentunya agar mahasiswa dan dosen terhindar dari Covid 19.

Berdasarkan hasil wawancara awal peneliti dengan mahasiswa bahwa dosen yang menggunakan aplikasi google classroom pada seemster 1 Program studi PGSD STKIP Taman Siswa Bima Tahun 2020-2021 adalah Mata Kuliah Konsep Dasar PKN dan Konsep Dasar IPS.

Adapun tujuan penelitian ini untuk mengetahui seberapa besar respon dan kesiapan mahasiswa dalam menggunakan aplikasi google classroom sehingga dapat mempermudah dosen dan mahasiswa dalam berinteraksi dalam pembelajaran. Kemudian apabila penggunaan aplikasi google classroom ternyata efektif dan memberikan kemudahan kepada mahasiswa. Maka pada semester-semester berikutnya aplikasi google classroom akan terus digunakan lebih khususnya di masa-masa pendemi seperti saat ini.

\section{METODE}

Penelitian ini menggunakan jenis penelitian kualitatif deskriptif dengan tehnik survey dalam mengumpulkan data dilapangan. Menurut (Iqbal, 2009) penelitian deskriptif adalah penelitian yang dilakukan untuk mengetahui nilai dari suatu variabel, dalam hal ini variabel mandiri, baik satu variabel atau lebih tanpa membuat perbandingan atau menghubungkan dengan variabel lain. Sementara instrumen penelitian yang digunakan adalah dengan metode angket dan wawancara. Sampel terdiri dari 70 orang mahasiswa semester 1 PGSD dibagi dalam 2 kelas yaitu kelas $\mathrm{G}$ sejumlah 30 orang dan Kelas H 40 orang. Angket diberikan kepada mahasiswa yang sedang mengikuti pembelajaran daring Mata Kuliah Konsep 
Dasar PKN. Jumlah pertanyaan diberikan sebanyak 15 pertanyaan dengan pilihan jawaban Sangat tidak setuju, Setuju, Ragu,

Tidak Setuju, Sangat tidak setuju. Sementara

Tabel 1. Angket Respon Mahasiswa

\begin{tabular}{|c|c|c|c|c|c|c|}
\hline \multirow[t]{2}{*}{ NO } & \multirow[t]{2}{*}{ INDIKATOR } & \multirow[t]{2}{*}{ PERNYATAAN } & \multicolumn{4}{|c|}{ JAWABAN } \\
\hline & & & SS & $\mathbf{R}$ & TS & STS \\
\hline 1 & 2 & $\begin{array}{l}\text { Saya lebih dapat memahami diskusi } \\
\text { kelompok melalui Google classroom } \\
\text { dibandingkan diskusi melalui aplikasi } \\
\text { lain }\end{array}$ & & & & \\
\hline 2 & & $\begin{array}{l}\text { Belajar PKN dengan Google classroom } \\
\text { membuat saya lebih paham }\end{array}$ & & & & \\
\hline 3 & 1 & $\begin{array}{l}\text { Saya dapat mengkases Goegle } \\
\text { Classroom dengan mudah dan } \\
\text { memahami cara menggunakan aplikasi }\end{array}$ & & & & \\
\hline 4 & & $\begin{array}{l}\text { Tampilan Goegle Classroom sangat } \\
\text { mudah dipahami }\end{array}$ & & & & \\
\hline 5 & 1 & $\begin{array}{l}\text { Di masa wabah covid, aplikasi Goegle } \\
\text { Classroom sangat membantu }\end{array}$ & & & & \\
\hline 6 & 2 & $\begin{array}{l}\text { Dengan aplikasi Goegle Classroom, } \\
\text { memperoleh informasi, materi maupun } \\
\text { pengumpulan tugas menjadi lebih } \\
\text { mudah dan fleksibel }\end{array}$ & & & & \\
\hline 7 & 1 & $\begin{array}{l}\text { Pembelajaran dengan aplikasi Google } \\
\text { class lebih mudah dibandingkan dengan } \\
\text { aplikasi lain. }\end{array}$ & & & & \\
\hline 8 & 1 & $\begin{array}{l}\text { Dengan google classroom saya dapat } \\
\text { menyimpan dokumen dengan mudah. }\end{array}$ & & & & \\
\hline 9 & 2 & $\begin{array}{l}\text { Dengan google classroom } \\
\text { memungkinkan mahasiswa umpan balik } \\
\text { dengan cepat }\end{array}$ & & & & \\
\hline 10 & 1 & $\begin{array}{l}\text { Menggunakan aplikasi google classroom } \\
\text { lebih menghemat quota dibandingkan } \\
\text { aplikasi zoom atau tatap muka. }\end{array}$ & & & & \\
\hline 11 & 2 & $\begin{array}{l}\text { Dengan menggunakan Goegle } \\
\text { Classroom memungkinkan saya } \\
\text { menyelesaikan tugas dengan cepat }\end{array}$ & & & & \\
\hline 12 & 2 & $\begin{array}{l}\text { Dosen aktif memberikan tanggapan, } \\
\text { diskusi dan pengumuman pada aplikasi } \\
\text { Google Classroom }\end{array}$ & & & & \\
\hline 13 & 1 & $\begin{array}{l}\text { Menggunakan Goegle Classroom dapat } \\
\text { menghemat biaya dan waktu }\end{array}$ & & & & \\
\hline 14 & 2 & $\begin{array}{l}\text { Menggunakan Goegle Classroom dapat } \\
\text { melihat langsung penilaian dan } \\
\text { pengumuman Dosen }\end{array}$ & & & & \\
\hline 15 & 2 & $\begin{array}{l}\text { Menggunakan Google Classroom } \\
\text { mahasiswa dapat belajar dimana saja }\end{array}$ & & & & \\
\hline
\end{tabular}

indikator angket adalah sebagai berikut : 1 . Kemudahan Dalam Akses Google Classroom 2. Pemahaman Materi Dalam Google Classroom. 


\begin{tabular}{lcc}
\hline No & Rentang Skor $(\%)$ & Kategori \\
\hline 1 & $84-100$ & Sangat setuju \\
\hline 2 & $68-84$ & Setuju \\
\hline 3 & $52-68$ & Ragu \\
\hline 4 & $36-52$ & Tidak setuju \\
\hline 5 & $20-36$ & Sangat tidak setuju \\
\hline
\end{tabular}

Tabel 3. Kelas Penggunaan Aplikasi Google Classroom.

\begin{tabular}{|c|c|c|}
\hline NO & $\begin{array}{c}\text { KELAS G } \\
\text { NAMA }\end{array}$ & $\begin{array}{c}\text { KELAS H } \\
\text { NAMA }\end{array}$ \\
\hline 1 & Putri Niva Nurviani & Lista Astrid \\
\hline 2 & Nurfadila & Nining \\
\hline 3 & Ainun Haryati & Usti koma \\
\hline 4 & Nikital Mardiyah & Putri Komalasari \\
\hline 5 & Andrilla & Erlinda \\
\hline 6 & Mira Wahyuni & Erika Putri Mandalika \\
\hline 7 & M. Zailani & Indriwati \\
\hline 8 & Ishaka & Taufik Hidayat \\
\hline 9 & Almuhaimin & Rofini \\
\hline 10 & Abdul Kabir & Asti \\
\hline 11 & M. Fauzan Adzim & Yadi Mulyadin \\
\hline 12 & Sumawardani & Nining Widyaastuti \\
\hline 13 & Anut Fatin & Eka Purwati \\
\hline 14 & Lilis Rahmawati & Jiatun Rahmah \\
\hline 15 & Putri Ramdani & Arafah \\
\hline 16 & Sri Wulandari & Andri Yawarman \\
\hline 17 & Feny Febriyani & Fara Dilah \\
\hline 18 & Vegi Melati Sukma & Aulia Rofiah \\
\hline 19 & Farija & Irmawaty \\
\hline 20 & Fauzia Ramadani & Anita Puspita \\
\hline 21 & Ainullah & Irwan \\
\hline 22 & Fahrul & Madiatun \\
\hline 23 & Wilda Umairah & sukma Ayu \\
\hline 24 & Nandini ramadanty & Muhammad Naufal \\
\hline 25 & Mutmainah & Jusi Rahmat \\
\hline 26 & Intan Herlintan & Sri Yayu \\
\hline 27 & Fahminisa & Hijriah \\
\hline 28 & Lifi Handayani & Anti Jumiati \\
\hline 29 & Rosyana & Anis Fitriani \\
\hline 30 & Nofa Rosalina & Taufikkurahman \\
\hline 31 & & Ayu Lestari \\
\hline 32 & & Linda Purwati \\
\hline 33 & & ST Halifah \\
\hline 34 & & Umratun \\
\hline 35 & & Laura Angely \\
\hline 36 & & Yanti Ardianti \\
\hline 37 & & Leni Lutfiani \\
\hline 38 & & Titin Hardianti \\
\hline 39 & & Rafli Indra Alam \\
\hline 40 & & Hasbulan \\
\hline
\end{tabular}


Perkuliahan Mahasiswa Semester 1 Program studi PGSD STKIP Taman Siswa Bima pada Mata Kuliah Konsep Dasar PKN yaitu pada Kelas G dan H. Bahwa ditemukan pada Kelas G 39 Mahasiswa yang mengumpulkan tugas dan 32 Orang pada kelas H. Sementara Materi yang diberikan atau diupload pada Google Classroom sebanyak 7 materi.

\section{HASIL DAN PEMBAHASAN Hasil}

Dalam pelaksanaan pembelajaran online ini. peneliti membuat dua kelas yang yaitu di Kelas $G$ dan Kelas $H$ sebagaimana tampilan sebagai berikut:

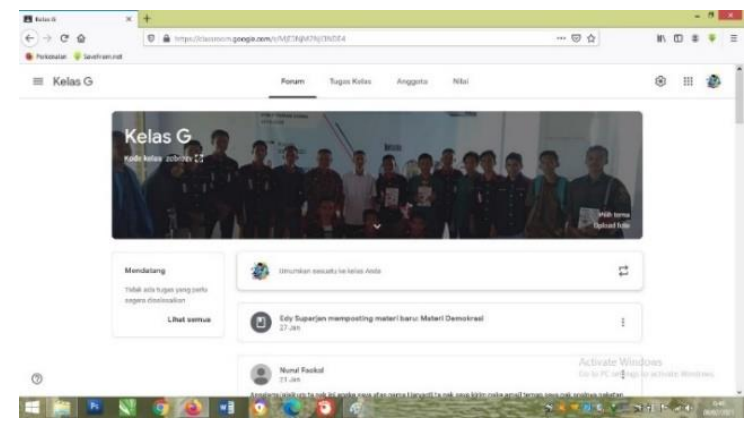

Gambar 1. Tampilan Kelas G

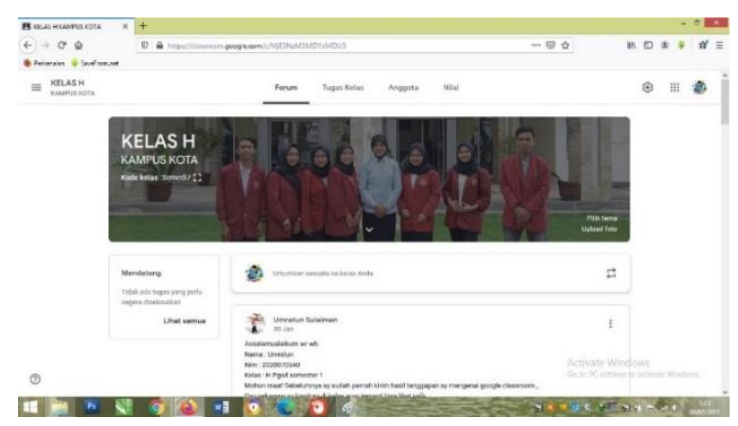

Gambar 2. Tampilan Kelas H

Adapun respon mahasiswa dalam penggunaan Google Classroom pada Mata Kuliah Konsep Dasar PKN di Program studi PGSD STKIP Taman Siswa Bima dapat dijelaskan sesuai indikator dibawah ini :

1. Respon Mahasiswa terhadap kemudahan dalam menggunakan Google Classroom

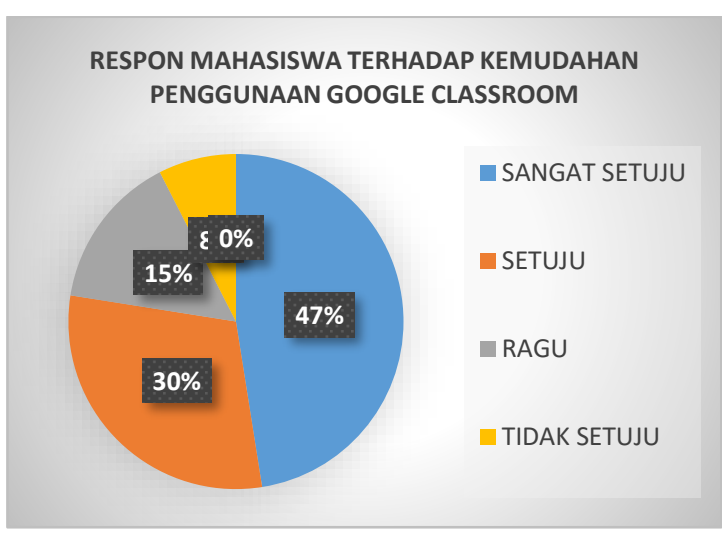

Gambar 3. Grafik Respon Mahasiswa Kelas H Terhadap kemudahan Penggunaan Google Classroom.

Berdasarkan hasil analisis data pada gambar 3 diatas bahwa pada Indikator pertama respon mahasiswa terhadap kemudahan menggunakan google classroom yaitu sebanyak 19 orang atau $47 \%$ yang menyatakan sangat setuju, 12 orang atau $30 \%$ menyatakan setuju, 6 orang atau $15 \%$ menyatakan ragu dan terdapat 3 orang atau sebesar $8 \%$ yang menyatakan tidak setuju. Tidak ada mahasiswa yang memilih pernyataan "sangat tidak setuju".

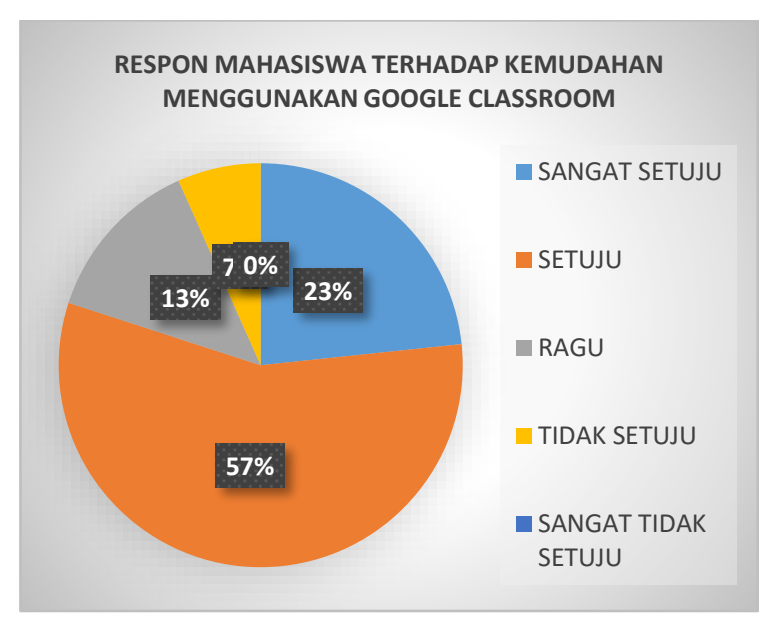

Gambar 4. Grafik Respon Mahasiswa Kelas G Terhadap Kemudahan Menggunakan Google Classroom.

Berdasarkan hasil analisis data pada gambar. 4 diatas bahwa pada Indikator pertama respon mahasiswa terhadap kemudahan menggunakan google classroom di Kelas G yaitu sebanyak 7 orang atau sebesar $23 \%$ yang menyatakan sangat setuju, sebanyak 17 orang atau sebesar 57\% menyatakan setuju, sebanyak 4 orang atau sebesar $13 \%$ menyatakan ragu. 
Sementara hanya 2 orang atau sebesar $7 \%$ yang menyatakan tidak setuju. Dan tidak ada yang menyatakan "sangat tidak setuju".

2. Pemahaman Materi dalam menggunakan Google Classroom

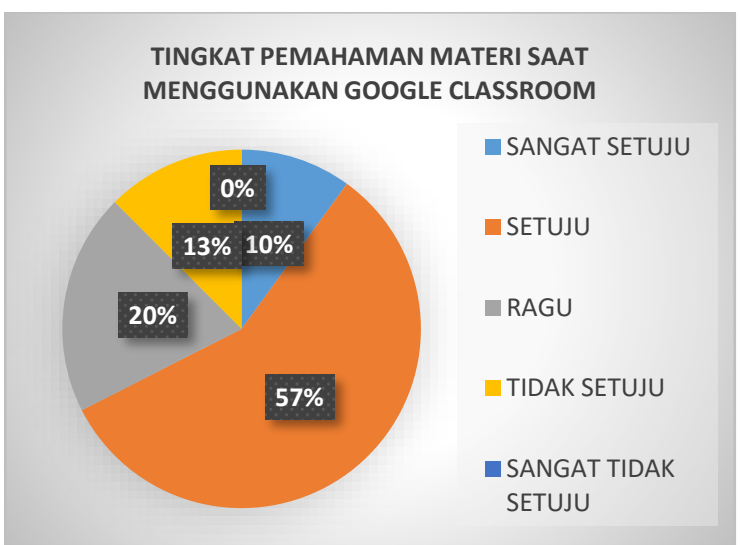

Gambar. 5. Grafik Pemahaman Materi Mahasiswa Kelas H dalam Google Classroom.

Berdasarkan hasil analisis data pada gambar. 5. diatas bahwa pada Indikator Kedua Pemahaman Materi saat menggunakan google classroom di Kelas $\mathrm{H}$ yaitu sebanyak 4 orang atau sebesar $10 \%$ yang menyatakan sangat setuju, sebanyak 23 orang atau sebesar $57 \%$ menyatakan setuju, sementara sebanyak 8 orang atau sebesar $20 \%$ menyatakan ragu dan terdapat 5 orang atau sebesar $13 \%$ yang menyatakan tidak setuju. Dan tidak ada mahasiswa memilih pernyataan "sangat tidak setuju". Untuk lebih jelas, pada gambar. 6 dan 7 adalah hasil respon mahasiswa terhadap tugas yang diberikan oleh dosen pembimbing.

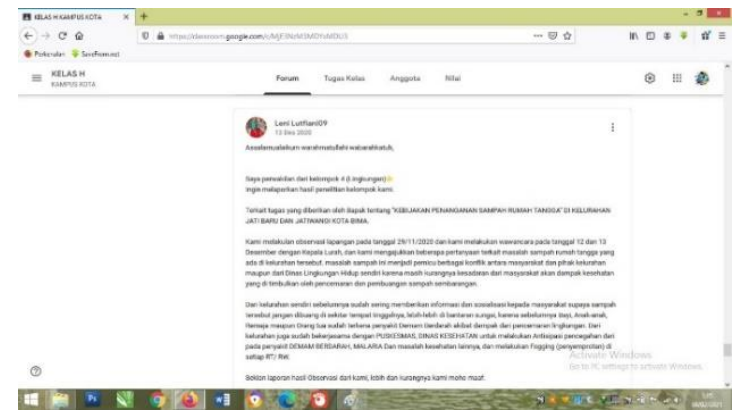

Gambar 6. Respon mahasiswa Kelas H

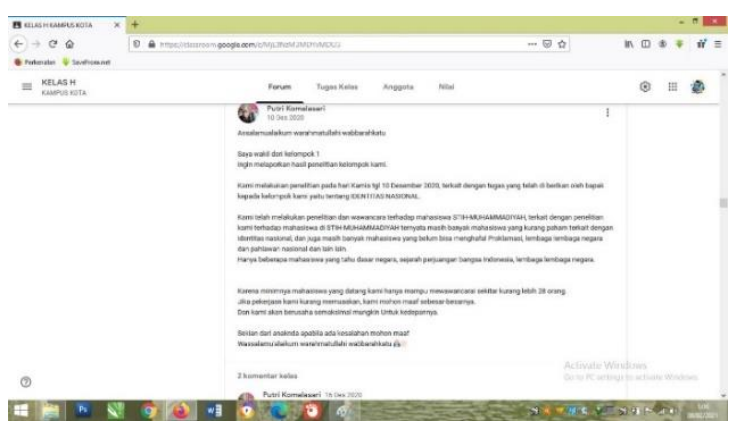

Gambar 7. Respon Mahasiswa Kelas H

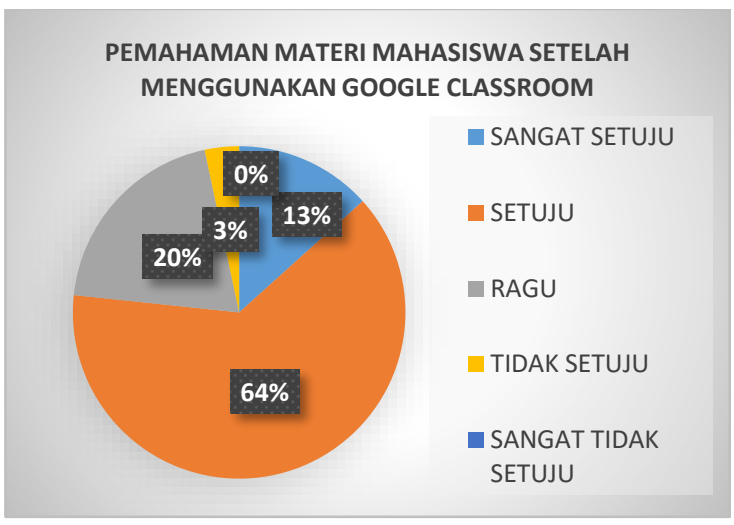

Gambar 8. Grafik Pemahaman Materi

Mahasiswa Kelas G dalam menggunakan Google Classroom.

Berdasarkan hasil analisis data pada gambar. 8. diatas bahwa pada Indikator Kedua Pemahaman Materi mahasiswa saat menggunakan google classroom di Kelas G yaitu sebanyak 3 orang atau sebesar 13\% yang menyatakan sangat setuju, sebanyak 19 orang atau sebesar $47 \%$ menyatakan setuju, sebanyak 6 orang atau sebesar $20 \%$ menyatakan ragu dan hanya 1 orang atau sebesar 3\% yang menyatakan tidak setuju. Sementara tidak ada mahasiswa yang memilih pernyataan "sangat tidak setuju". Pada gambar. 9 merupakan hasil respon mahasiswa terhadap pemahaman materi yang diberikan oleh Dosen Pembimbing.

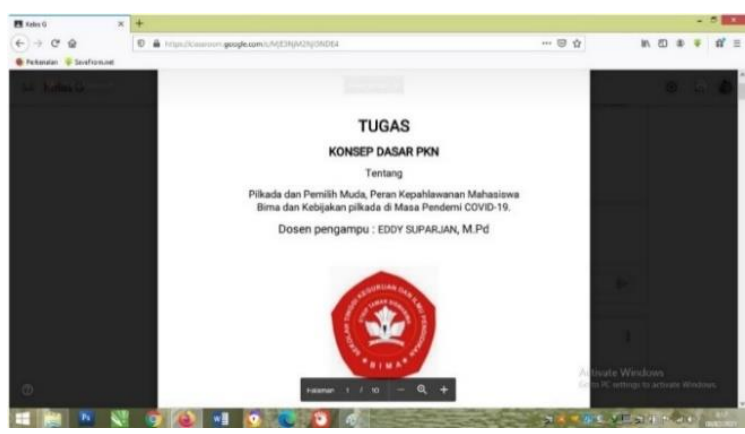




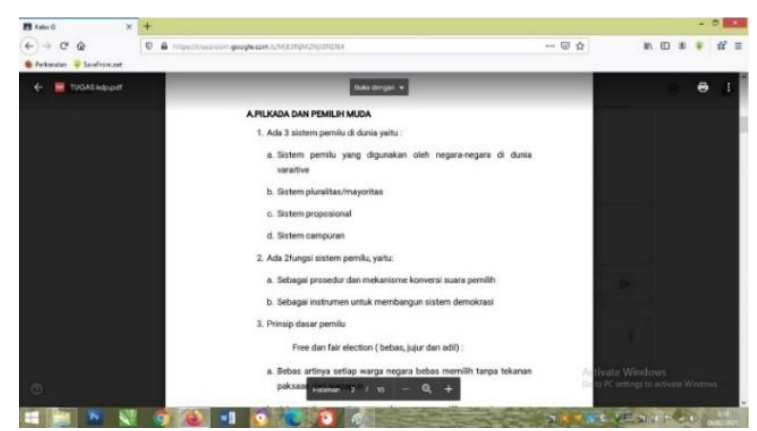

Gambar 9. Tugas Mahasiswa Kelas G

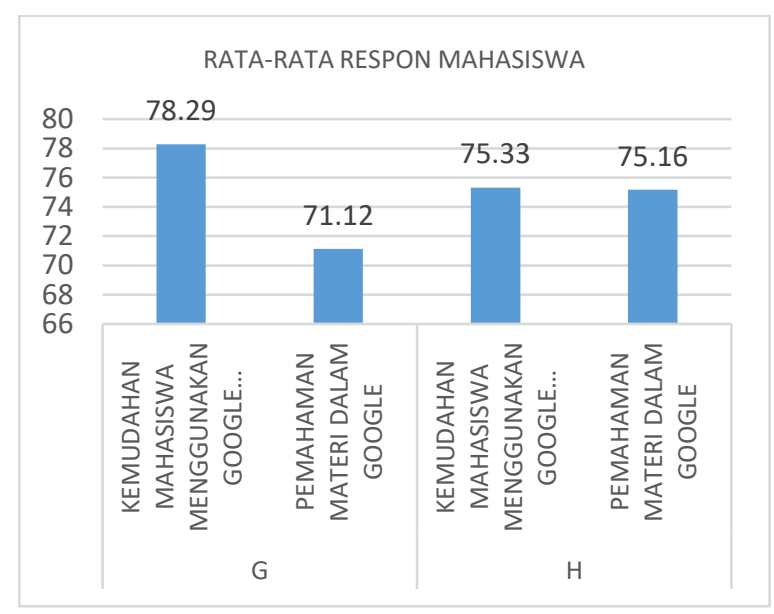

Gambar. 10. Grafik rata-rata respon mahasiswa per indikator kelas

Berdasarkan hasil analisis data pada gambar. 5 diatas bahwa rata-rata respon mahasiswa terhadap penggunaan Google Classroom pada tiap indikator penelitian adalah paling tinggi pada indikator pertama sebanyak 78,29\% di Kelas $\mathrm{G}$ dan indikator pemahaman materi dalam google classroom sebesar $71,12 \%$ berada pada kategori setuju. Sementara di Indikator pertama tentang kemudahan mahasiswa menggunakan google classroom pada Kelas $\mathrm{H}$ sebesar $75,33 \%$ dan Indikator Pemahaman Materi dalam Google Classroom sebesar $75,16 \%$ yaitu berada pada kategori setuju. Ini artinya rata-rata tingkat respon mahasiswa terhadap penggunaan Google Classroom berada pada kategori tinggi atau setuju. Karena mahasiswa merasakan bahwa menggunakan aplikasi Google Classroom sangat praktis dan memberikan kemudahan pada mahasiswa baik dalam menguggah maupun mengupload materi dan tugas serta tidak terlalu membebani mahasiswa dalam hal quota/paket internet.

\section{Pembahasan}

Dari hasil analisis data diatas dapat diketahui bahwa penggunaan google classroom cukup efektif dalam pelaksanaan pembelajaran daring tentunya dengan menggunakan pendekatan kontekstual. Dalam proses pembelajaran ada beberapa tahapan yang dijalankan oleh Dosen Pembimbing yaitu mulai pembuatan akun Google Classroom, menyiapkan materi ajar, lalu mengunggah materi kedalam aplikasi Google Classroom. Materi yang diberikan pada kuliah ini adalah Ideologi Pancasila, Identitas Nasional, Demorasi, Konstitusi, HAM, Wawasan Nusantara. Materi yang diberikan dalam bentuk Pdf maupun powerpoint. Pada Kolom komentar digunakan untuk memberikan tugas, mengumumkan pekerjaan rumah serta kuiskuis. Setiap pemberian tugas, mahasiswa merespon dan menanyakan kapan pengumpulan tugas serta bagaimana cara mengumpulkannya. Dapat dilihat pada gambar Respon Gambar 6 \& 7.

Berdasarkan hasil analisis data diatas menunjukan bahwa rata-rata respon mahasiswa terhadap penggunaan Google Classroom dapat dibagi dua kelas yaitu Kelas $\mathrm{G}$ dan Kelas $\mathrm{H}$. Dapat dijelaskan sebagai berikut :

1. Kelas G. pada indikator pertama sebanyak $78,29 \%$ dan indikator kedua sebesar 71,12\% berada pada kategori setuju.

2. Kelas H Sebagai berikut. Indikator pertama tentang kemudahan mahasiswa menggunakan google classroom sebesar 75,33\% dan Indikator Pemahaman Materi dalam Google Classroom sebesar 75,16\% yaitu berada pada kategori setuju.

Ini artinya rata-rata tingkat respon mahasiswa terhadap penggunaan Google Classroom berada pada kategori tinggi atau setuju. Hal ini mahasiswa merasakan bahwa menggunakan aplikasi Google Classroom sangat praktis dan memberikan kemudahan pada mahasiswa baik dalam menguggah maupun mengupload materi dan tugas serta tidak terlalu membebani mahasiswa dalam hal quota/paket internet. Sehingga pada perkuliahan semester berikutnya, peneliti akan menerapkannya pada Mata Kuliah lain. 
Penelitian ini juga memperkuat penelitian yang dilakukan Utami, 2019, Suci Ramdhani Arifin, 2020 serta Sugama Maskar, 2019.

\section{KESIMPULAN}

Berdasarkan hasil analisis data diatas dapat disimpulkan bahwa rata-rata respon mahasiswa terhadap penggunaan Google Classroom pada tiap indikator penelitian adalah paling tinggi pada indikator pertama sebanyak $78,29 \%$ di Kelas $\mathrm{G}$ dan indikator pemahaman materi dalam google classroom sebesar $71,12 \%$ berada pada kategori setuju. Sementara di Indikator pertama tentang kemudahan mahasiswa menggunakan google classroom pada Kelas $\mathrm{H}$ sebesar 75,33\% dan Indikator Pemahaman Materi dalam Google Classroom sebesar $75,16 \%$ yaitu berada pada kategori setuju. Sehingga penggunaan aplikasi google Classroom sangat diterima baik oleh mahasiswa karena dapat memberikan kemudahan bagi mahasiswa dalam menguggah materi dari dosen serta mengupload tugas-tugas yang dikumpulkan baik secara individu maupun kelompok.

\section{DAFTAR PUSTAKA}

Aji, S., \& Halal, R. (2020). Dampak Covid 19 Pada Pendidikan di Indonesia. Jurnal Sosial dan budaya Syari-i.

Arifin, S. R., \& Merdekawati, e. G. (2020). Tanggapan Mahasiswa Terhadap Pemanfaatan Google Classroom sebagai Media Pembelajaran Online. Jurnal Sistem dan Teknologi Informasi, 2620-8989.

Azhar, A. (2014). Media Pembelajaran. Jakarta: Rajawali Press.

Deni, D. (2012). Teknologi dan Informasi Teori dan Aplikasi. Bandung: Rosda Karya.

Iqbal, H. (2009). Analisis Data Penelitian dengan Statistik. Jakarta: Bumi Aksara.

Maskar, S., \& Wulantina, E. (2019). Persepsi Peserta didik terhadap Metode Blended Learning dengan Google Classroom. Jurnal Inomatika, Vol, 1 No. 2.
Pribadi, B. A. (2011). Model ASSURE untuk mendesain Pembelajaran Sukses. Jakarta: Dian Rakyat.

Suhada, I., \& et.al. (2020). Pembelajaran Daring Berbasis Google Classroom Mahasiswa Pendidikan Biologi pada masa Wabah Covid 19. Jurnal UIN Sunan Kalijaga, -.

Utami, R. (2019). Analisis Respon Mahasiswa terhadap Penggunaan Google Classroom pada Mata Kuliah Psikoogi Pembelajaran Matematika. Prosiding Seminar Nasional Matematika, PRISMA 2, 2613-9189. 